\title{
Offshore Distances of Bowhead Whales (Balaena mysticetus) Observed during Fall in the Beaufort Sea, 1982-2000: An Alternative Interpretation
}

\author{
STEPHEN D. TREACY,,$^{1,2}$ JEFFREY S. GLEASON ${ }^{1,3}$ and CLEVELAND J. COWLES ${ }^{1}$
}

(Received 11 April 2005; accepted in revised form 25 August 2005)

\begin{abstract}
Nineteen years (1982-2000) of sighting data from fall aerial surveys of bowhead whales (Balaena mysticetus) in the Alaskan Beaufort Sea were analyzed to determine how patterns in the distribution of migrating bowhead whales relate to annual sea-ice conditions. Transect sighting rate (transect sightings $/ \mathrm{km}$ ) indicated (ANOVA; $\mathrm{F}_{2.980}=143.84, p<0.0001$ ) that bowhead whales occurred farther offshore in years of heavy ice conditions $(73.4 \mathrm{~km}, 95 \%$ CL: $67.2-79.6 \mathrm{~km})$ than in years of moderate (49.3 km, 95\% CL: $44.8-53.84 \mathrm{~km})$, or light (31.2 km, 95\% CL: 30.0-32.4 km) ice conditions. The most plausible explanation for the observed pattern in bowhead whale distribution is that in years of heavy ice conditions (annual pack ice; 1983, 1988, 1991), the developing landfast ice limits availability of shallow nearshore habitat, thus necessitating use of leads and ice openings in deeper water. We acknowledge that factors such as bathymetry, ocean currents, transport, and food availability may also interact to influence autumn distribution of bowhead whales. In heavy ice years, however, these factors likely exert less influence on bowhead whale distribution than in years with light to moderate ice conditions.
\end{abstract}

Key words: Alaska, Arctic, Balaena mysticetus, Beaufort Sea, bowhead whales, distribution, ice cover, migration

RÉSUMÉ. Les données automnales prélevées à partir de relevés aériens pendant 19 années chez les baleines boréales (19822000) (Balaena mysticetus) de la mer de Beaufort alaskienne ont été analysées dans le but de déterminer comment les tendances caractérisant la répartition des baleines boréales en migration se rapportent à l'état annuel des glaces et de la mer. Le taux de repérage transect (repérage transect $/ \mathrm{km}$ ) a indiqué (ANOVA; $\left.\mathrm{F}_{2,980}=143.84, p<0,0001\right)$ que les baleines boréales se trouvaient plus loin au large pendant les années où il y avait beaucoup de glace (73,4 km, $95 \%$ CL: 67,2-79,6 km) que pendant les années où la glace était modérée (49,3 km, $95 \%$ CL: 44,8-53.84 km) ou légère $(31,2 \mathrm{~km}, 95 \%$ CL: 30,0-32,4 km). L'explication la plus plausible à la source de la tendance qui a été observée en matière de répartition des baleines boréales, c'est que pendant les années où il y a beaucoup de glace (banquise; 1983, 1988, 1991), la glace de rive en formation limite la disponibilité d'habitats de faible profondeur à proximité du littoral, ce qui nécessite l'utilisation de chenaux et d'ouvertures dans la glace en eau plus profonde. On reconnaît que des facteurs comme la bathymétrie, les courants océaniques, le transport et la disponibilité de la nourriture peuvent également entrer en interaction au point d'exercer une influence sur la répartition automnale des baleines boréales. Cependant, pendant les années où il y a beaucoup de glace, ces facteurs sont susceptibles d'exercer moins d'influence sur la répartition des baleines boréales que pendant les années où la couverture de glace varie de légère à moyenne.

Mots clés : Alaska, Arctique, Balaena mysticetus, mer de Beaufort, baleines boréales, répartition, couverture de glace, migration

Traduit pour la revue Arctic par Nicole Giguère.

\section{INTRODUCTION}

The annual cycle of sea ice in the Beaufort Sea and its effect on general habitat availability for bowhead whales are well documented (Moore and Reeves, 1993). Bowhead whales (Balaena mysticetus) are generally thought to be closely associated with sea ice, at least for part of the year (Burns et al., 1981). In the fall, a portion of the Western Arctic stock of bowhead whales migrates westward from the Canadian Beaufort Sea and Amundsen Gulf, past Point Barrow, Alaska, through the Chukchi Sea, and into the
Bering Sea. Their migration begins in August and continues into November, depending on ice conditions (Ljungblad et al., 1986b; Moore and Reeves, 1993). Traditionally, there has been a tendency to extrapolate migration behavior observed during fall in the Alaskan Beaufort Sea to represent behavior for the entire Western Arctic (or BeringChukchi-Beaufort) stock of bowhead whales (Shelden and Rugh, 1995; Angliss and Lodge, 2002). It is becoming increasingly clear, however, that numbers of bowheads observed during autumn aerial surveys off the north coast of Alaska vary substantially from year to year and that the

\footnotetext{
${ }^{1}$ United States Department of the Interior, Minerals Management Service, 3801 Centerpoint Drive, Suite 500, Anchorage, Alaska 99503-5820, U.S.A.

${ }^{2}$ Current address: 101 S. Palmer Drive, Port Townsend, Washington 98368, U.S.A.

${ }^{3}$ Corresponding author: jeff.gleason@mms.gov

(C) The Arctic Institute of North America
} 
number of whales encountered in any one year actually represents a small fraction $(<10 \%$; Minerals Management Service, unpubl. data) of the Western Arctic stock (George et al., 2004). During the migration through the central Alaskan Beaufort Sea, many of the migrating whales tend to select inner and outer shelf waters with little to no ice (Moore et al., 2000), presumably to take advantage of available zooplankton (i.e., copepods and euphasiids; Lowry, 1993). In some years, bowheads may congregate and feed in nearshore waters (Lowry and Frost, 1984; Lowry, 1993) early in the ice-free period (August-September), though such aggregations have been documented near Point Barrow well into October (Landino et al., 1994). It is during this transition from relatively openwater to ice-dominated conditions that whale behavior tends to shift from "social" (e.g., feeding, milling, resting) to predominantly "migratory" (e.g., swimming and diving) movements, with whales swimming medium to fast (Ljungblad et al., 1986c).

The U.S. Department of the Interior has sponsored spring and fall aerial surveys of bowhead whales in the Beaufort Sea for monitoring purposes since 1979 (Treacy, 2002), and the present research is considered a follow-up to previous work (Moore and Clarke, 1992; Moore and Reeves, 1993; Moore and DeMaster, 1997; Moore, 2000; Moore et al., 2000). One goal of the current monitoring project is to describe distribution and movement patterns of bowhead whales in the fall, when they migrate westward across the Alaskan Beaufort Sea. Here, we include analysis of offshore distance of bowhead whales encountered during fall surveys and describe the pattern of bowhead distribution as a function of annual sea-ice conditions. The extensive aerial survey database that we analyzed overlaps somewhat that analyzed by Moore (2000), Moore et al. (2000), and others (1982-91), but our analysis includes more recent information (1992-2000) and an alternative interpretation of the data.

\section{METHODS}

\section{Study Area and Survey Protocol}

The fall bowhead aerial survey project is based on a set of random field transects within established geographic blocks (Survey Blocks 1-12, Fig. 1) in Chukchi and Beaufort Sea offshore areas along the north Alaskan coast $\left(140-157^{\circ} \mathrm{W}\right.$ longitude and south of $72^{\circ} \mathrm{N}$ latitude). Surveys have operated from Deadhorse (Prudhoe Bay), Alaska. The primary survey platform, a de Havilland Twin Otter, was equipped with an additional fuel tank within the passenger compartment to maximize long-range capability. The aircraft was also fitted with two medium-sized bubble windows behind the cabin bulkhead and one on the aft starboard side that afforded complete trackline viewing. Observers and pilots were linked to common communication systems so that sightings of marine mammals could be relayed between observers, increasing the probability of detection while decreasing the potential for resampling. A portable laptop computer was used aboard the aircraft to store and analyze flight data (using Visual Basic) and observational data (using Microsoft Access). The aircraft was equipped with either a Global Navigation System (GNS 500) or a Garmin III Global Positioning System (GPS) with an external aircraft antenna that provided continuous position updating. A custom moving map in Visual Basic permitted observers to view the aircraft's trackline in real time. A multi-columnar data table permitted several entries of sighting and positionupdate data to be logged and edited simultaneously. Data on sightings included date, time, latitude and longitude, altitude, aircraft position, sea state (Beaufort Scale; Chapman, 1977), ice cover (percent of sea surface), species, total number, behavior, size (adult, subadult, cowcalf pair), swim direction and speed (if applicable), and inclinometer angle. Surveys were generally flown at a target altitude of $462 \mathrm{~m}$ (1500 feet) and a flight speed of roughly $220-250 \mathrm{~km} / \mathrm{h}(120-140$ knots $)$. Surveys were aborted when cloud ceilings were consistently less than $305 \mathrm{~m}$ (1000 feet) or when sea state was consistently over Beaufort 4 (Moore et al., 2000:434). Daily flight patterns were based on sets of unique computer-generated transect grids for each survey block given constraints of local weather patterns.

\section{Data Sorting and Analysis}

Sea-ice conditions were grouped into three categories (heavy, moderate, and light) on the basis of data obtained from the United States Navy/NOAA Joint Ice Center (Navy/NOAA, 2002). Data obtained from the Joint Ice Center are relevant to our study because they provide a reasonable delineation of ice conditions for the Beaufort Sea study area and because there was a strong relationship (see Moore, 2000) between Navy/NOAA records and the year-rank based on ice conditions observed during surveys. For each year analyzed, we refined Joint Ice Center (JIC) rankings of sea-ice severity using their point system, which takes into account (a) distance (nautical miles; hereafter nmi) from Point Barrow northward to the ice edge on 15 September, (b) distance from Point Barrow northward to the five-tenths ice-concentration boundary on 15 September, (c) number of days the entire sea route to Prudhoe Bay was ice-free, (d) number of days the entire sea route to Prudhoe Bay was less than five-tenths ice concentration, and (e) number of days from the initial date the entire sea route to Prudhoe Bay was less than fivetenths ice concentration through 1 October. September 15 was chosen because it fell within the month with the greatest number of bowhead whale sightings and more appropriately describes ice conditions encountered by whales across the survey period (early August to late October, but generally the survey starts on or about 1 September). Sea-ice rankings were a sum of the scores for 


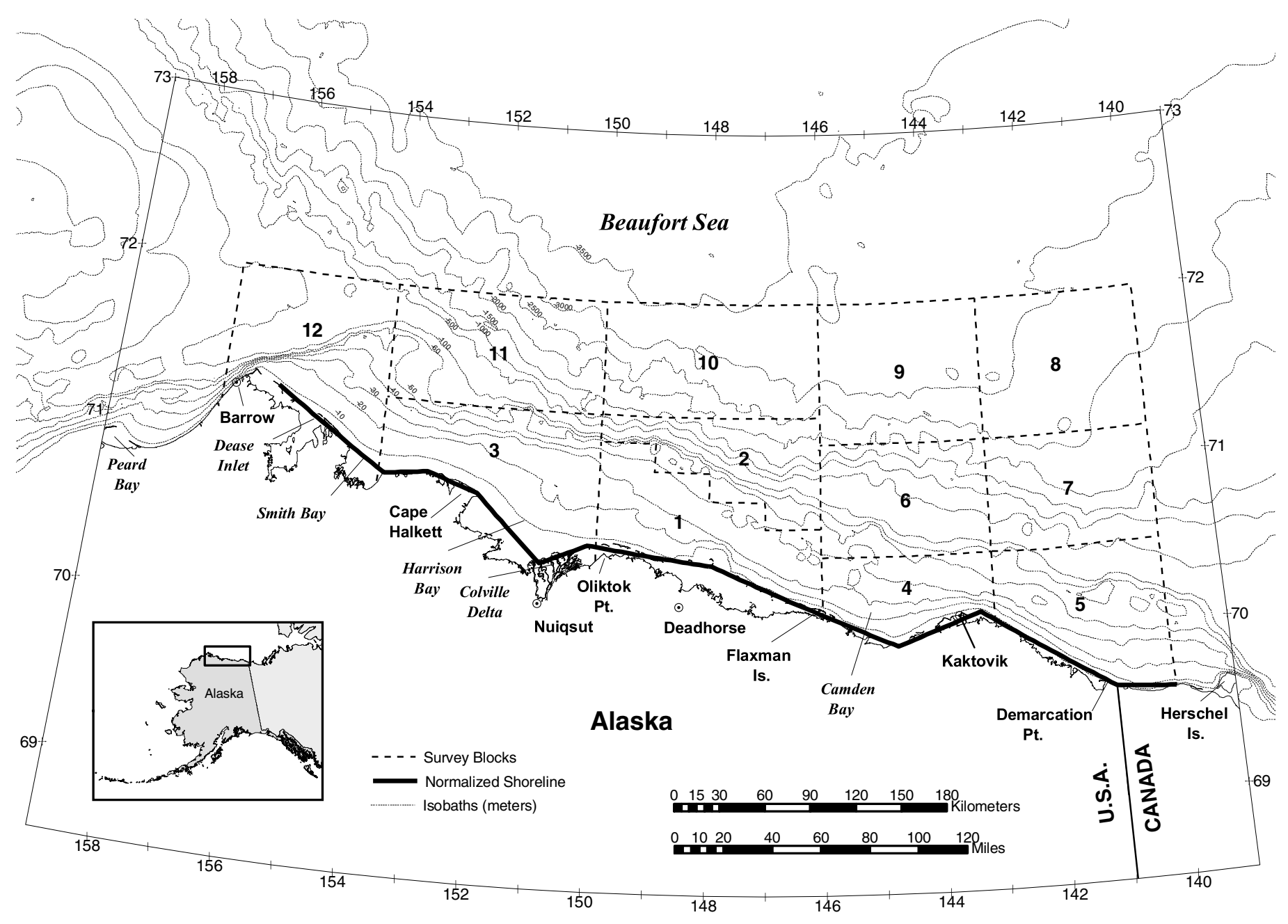

FIG. 1. Graphical representation of the aerial survey study area depicting survey blocks, normalized shoreline, isobaths, and important regional landmarks in the Beaufort Sea, Alaska.

all five categories (described above) recommended by JIC personnel. Using this system, we categorized ice conditions as heavy ( $>250$ points), moderate ( $125-249$ points), or light $(0-124$ points). Even though we recognize that intra- and inter-annual variation exists relative to freezeup, we believe that JIC rankings provide an appropriate basis for classification of sea-ice conditions used in the present study.

We classified 1983, 1988, and 1991 as having heavy ice conditions. Distance from Point Barrow to the five-tenths ice concentration on 15 September ranged from 16 to $40 \mathrm{~km}$ (10 to $25 \mathrm{nmi}$ ). We considered 1984, 1985, and 1992 as having moderate ice conditions: the same distance range was 40 to $121 \mathrm{~km}$ ( 25 to $75 \mathrm{nmi}$ ). The years 1982 , 1986, 1987, 1989, 1990, and 1993-2000 were categorized as having light ice conditions, and the distance ranged from 80 to $386 \mathrm{~km}$ (50 to $240 \mathrm{nmi}$ ). We assumed that heavy, moderate, and light classifications relative to pack ice were also indicative of landfast ice conditions for that year.

To examine preliminary patterns in fall bowhead distribution, we generated maps based on Universal Transverse
Mercator coordinates for each sighting, using a geographical information system (GIS) (ArcView, Vers. 3.2; ESRI, 1999). Though informative, maps of raw sighting data may not be representative of actual observations because of spatial differences in sampling effort, in part attributed to local weather patterns. We therefore accounted for sighting effort in our analysis by applying a grid matrix superimposed across the study area using the GIS. The matrix consisted of approximately equilateral grid cells sized $5^{\prime}$ latitude by $15^{\prime}$ longitude. Sighting rates for each grid cell were calculated as the number of sightings made on transect per kilometer flown in September and October. We "standardized" the shoreline by connecting with straight lines 11 points across the Beaufort Sea coast from $156^{\circ}$ to $140^{\circ} \mathrm{W}$ (Treacy, 2002). Inclusion of a standardized shoreline provided a frame of reference to evaluate annual deviations from a "migration axis." In addition, the standardized shoreline accounted for discontinuities in shoreline configuration from east to west relative to distance offshore for bowhead whale observations. The study area was bounded in the east by the shoreline at roughly $69.5^{\circ} \mathrm{N}$, 


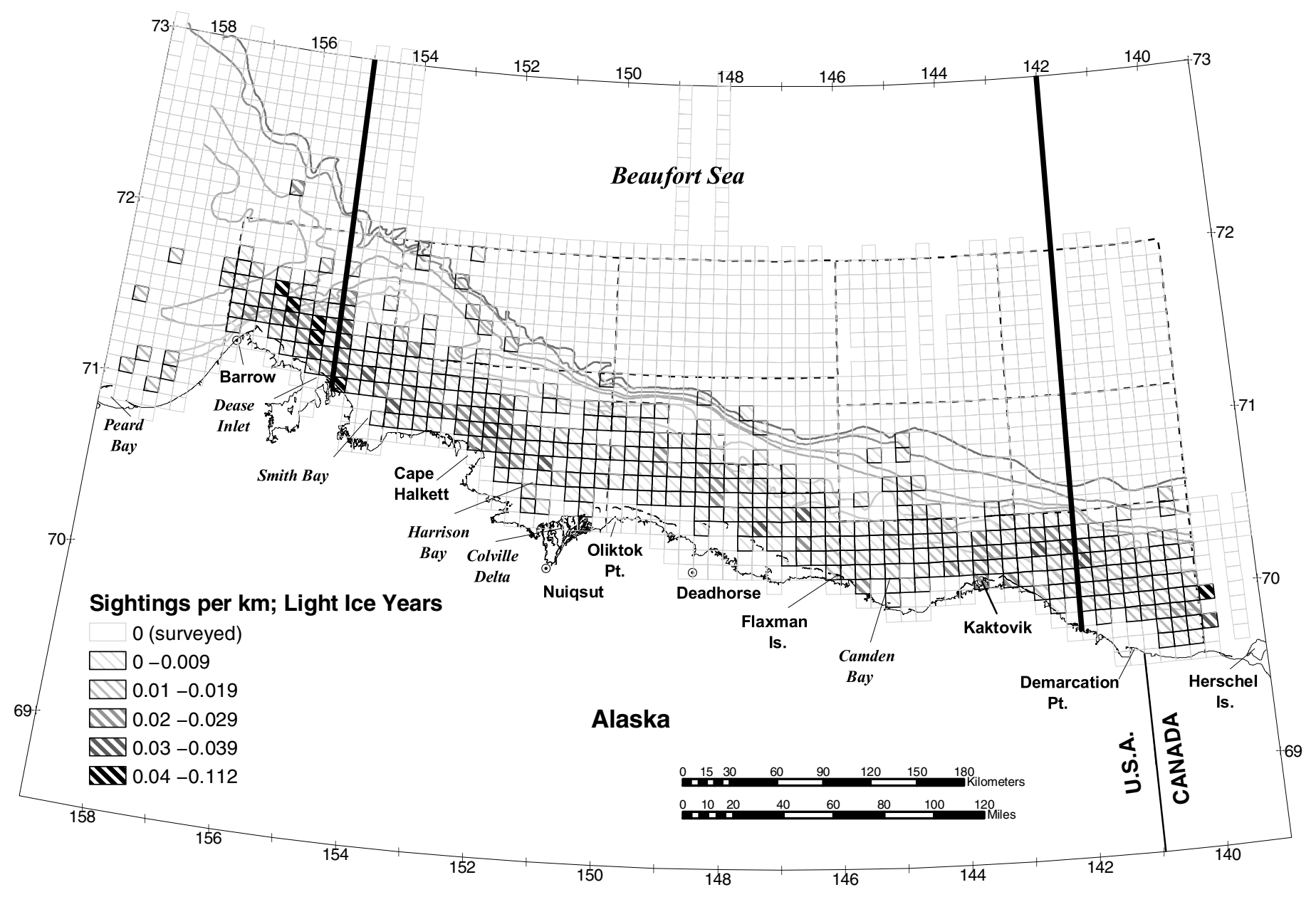

FIG. 2. Sighting rates in light-ice years (1982, 1986-87, 1989-90, 1993-2000) for bowhead whales (Balaena mysticetus) in the Alaskan Beaufort Sea. Rates from annual fall survey of the Bowhead Whale Aerial Survey Project (1982-2000) are adjusted for effort on transects during the relevant ice conditions. Aerial survey effort was likely greater within the area bounded by the dark vertical bars $\left(142^{\circ} \mathrm{W}\right.$ and $\left.155^{\circ} \mathrm{W}\right)$ because of local weather patterns and level of offshore oil and gas activities.

$140^{\circ} \mathrm{W}$ and in the west by the shoreline near Barrow at roughly $71^{\circ} \mathrm{N}, 156^{\circ} \mathrm{W}$ (Fig. 1).

We used a one-way Analysis of Variance (ANOVA) to evaluate distances from the standardized shoreline to locations of bowhead whale sightings. In this paper, a sighting represents one whale or more whales in apparent association (on-transect whales only) and does not include dead whales or repeat observations. In the analysis, distance offshore from a standardized shoreline represents a continuous response variable with categorical sea-ice condition as a main effect. We limit our inferences to the target population; that is, the results described below include only those bowhead whales observed on transect within the study area during the period of observation. We did not consider whales potentially "missed" (i.e., under water, under ice, or on surface, but not seen) in the analysis, nor did we consider whales not observed because they were present outside the survey period or beyond the geographical coverage of the study area. We used Tukey HSD as a post hoc multiple comparison procedure because this test sets experiment-wise error rate to that of all pair-wise comparisons (Wilkinson and Coward, 1999). All tests were performed using STATISTICA (StatSoft, 1995), and alpha level was set at $p=0.05$.

\section{RESULTS}

Distance offshore to bowhead whales was related to ice conditions $(F=143.84, \mathrm{df}=2,980 ; p<0.0001)$. Post-hoc comparisons indicated differences (Tukey HSD; $p<0.0001$ ) among the three ice-cover categories. Bowhead whales occurred farther offshore in years of heavy ice conditions $(73.4 \mathrm{~km}, 95 \%$ CL: $67.2-79.6 \mathrm{~km})$ than in years of moderate $(49.3 \mathrm{~km}, 95 \% \mathrm{CL}: 44.8-53.84 \mathrm{~km})$ or light $(31.2 \mathrm{~km}$, 95\% CL: $30.0-32.4 \mathrm{~km}$ ) ice conditions (Figs. 2-4). For sightings $(n=864)$ during years of light ice conditions (1982, 1986, 1987, 1989, 1990, and 1993-2000), highest sighting rates of bowhead whales generally occurred in shallower, near-shore waters reflecting coastal contours (Fig. 2). For sightings $(n=74)$ in years of moderate ice conditions (1984, 1985, and 1992), whales were generally observed in mid-range waters inshore from the shelf break (Fig. 3). For sightings $(n=45)$ in years of heavy ice 


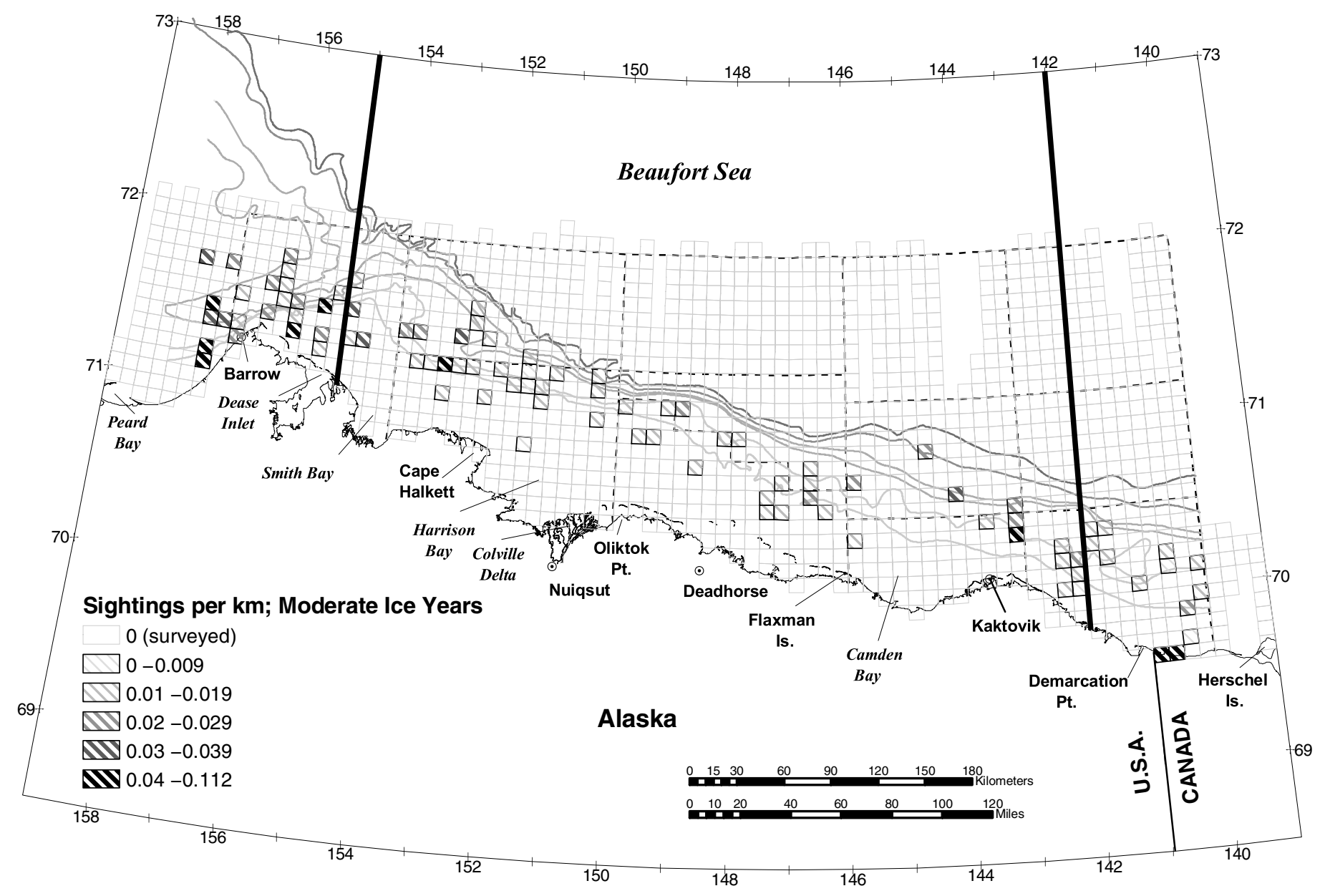

FIG. 3. Sighting rates in moderate-ice years $(1984-85,1992)$ for bowhead whales (Balaena mysticetus) in the Alaskan Beaufort Sea (survey information as in Fig. 2).

conditions (1983, 1988, and 1991), the whales observed occupied deeper, offshore waters near the shelf break (Fig. 4). These results primarily describe whales within the central Beaufort Sea portion of the study area (142$155^{\circ} \mathrm{W}$ longitude; see vertical bars in Figs. 2-4), as this pattern was not nearly as evident east of Kaktovik and west of Dease Inlet.

\section{DISCUSSION}

In general, fall aerial surveys in the central Alaskan Beaufort Sea showed that bowhead whale distribution was strongly influenced by sea-ice conditions (Figs. 2-4). During years of moderate to heavy sea-ice conditions, bowhead whales frequented deeper slope waters (200 to $2000 \mathrm{~m}$ ) than in light-ice years, when whales concentrated in inner-shelf waters $(<50 \mathrm{~m})$ (Fig. 2; see also Fig. 1 in Moore, 2000). Mate et al. (2000) found that 65\% (259 of 400 useable fixes) of satellite-acquired locations for eight juvenile bowhead whales tagged near Shingle Point, Northwest Territories, Canada, occurred in depths of 0 to $50 \mathrm{~m}$ irrespective of ice conditions. Though we did not consider water depth (bathymetry) per se in this analysis, bowhead whales in the Beaufort Sea do tend to occur more frequently in depths under $100 \mathrm{~m}$ (Mate et al., 2000; Moore, 2000 ) and may relate to water depth as a function of ice conditions or local feeding opportunities (Lowry, 1993) when pack ice or new landfast ice becomes an impediment to movements. Numerous other factors may contribute to fall distribution of bowhead whales in the Beaufort Sea, particularly in light-ice years. Such factors include (but are not limited to) bathymetry, transport or current (Moore, 2000), food availability (Lowry and Frost, 1984; Lowry, 1993; Landino et al., 1994), and their interactions. Considering the strength of association noted above, we believe these factors may be less important under moderate or heavy ice conditions because changes in the ocean environment presumably influence habitat-use decisions by bowhead whales. That is, as landfast ice advances and annual pack ice moves shoreward, coming into contact with the floating fast ice, a zone of ridging develops (see Barnes et al., 1978), thus restricting habitat available to migrating whales. This relatively brief transition in which ridging occurs likely results in a concomitant change in whale behavior; at this time, whales are observed almost exclusively in offshore leads and ice openings. 


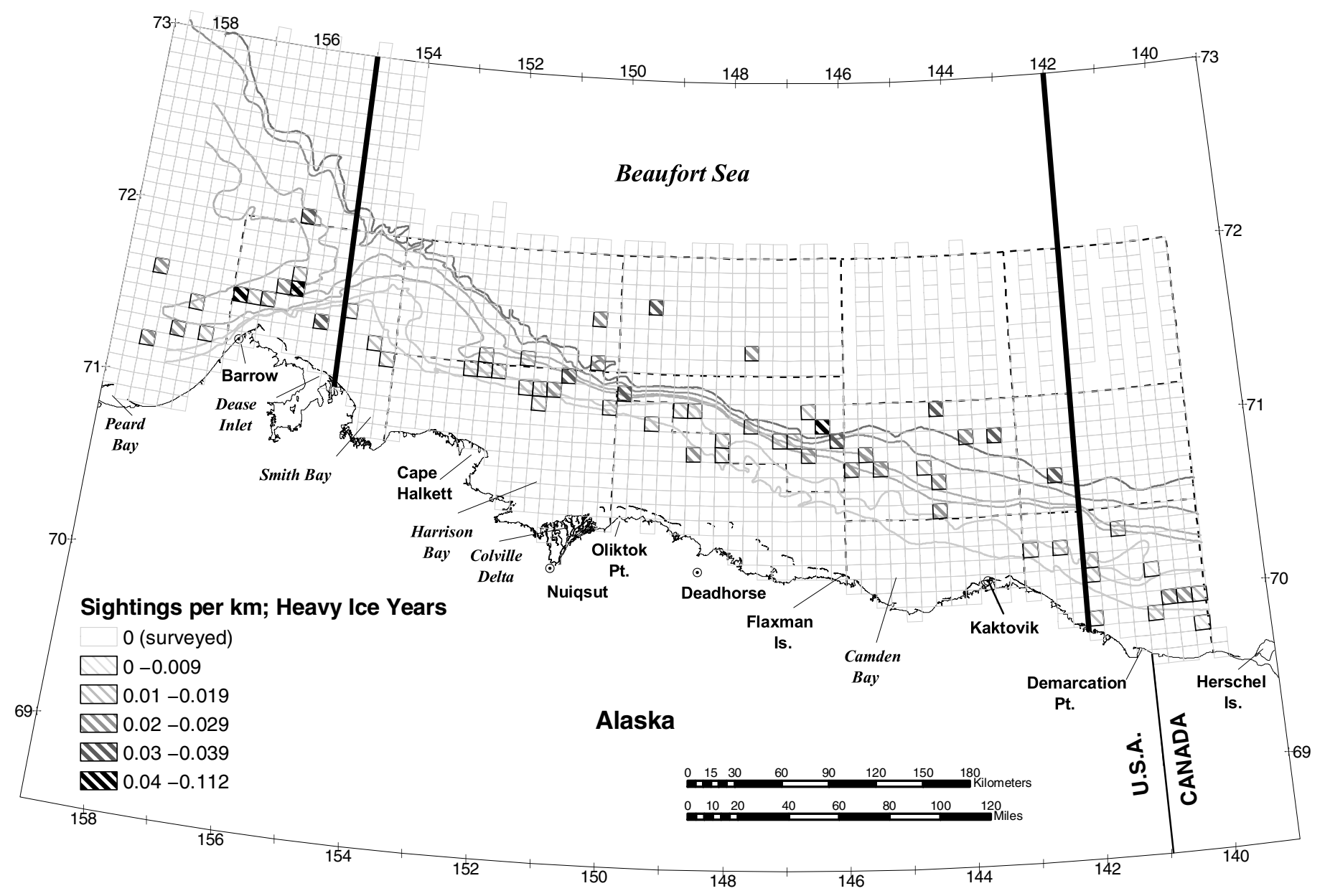

FIG. 4. Sighting rates in heavy-ice years $(1983,1988,1991)$ for bowhead whales (Balaena mysticetus) in the Alaskan Beaufort Sea (survey information as in Fig. 2).

We acknowledge that ice conditions at Barrow or Prudhoe Bay may not be representative of ice conditions at Kaktovik; however, we feel that the "point system" used in this paper to describe annual ice conditions and the subsequent rankings are justified and provide a reasonable proxy for conditions across the Beaufort Sea, at least at a large spatial scale. Ice conditions may vary spatially on a given date and temporally within a given survey year, though generally spatial variation is lessened for extremely heavy ice years or when open water persists for almost the entire survey period (i.e., light ice conditions). For the most part, ice-cover categories defined in the paper agree with those of Moore (2000). Heavy-ice years defined in our study $(1983,1988$, and 1991) were similar to those noted by Moore (2000). A difference was documented for moderate versus light ice conditions, and only for two years (1982 and 1987). Moore (2000:450) considered 1982 and 1987 as moderate-ice years, while we ranked them as light-ice years. These differences are likely due to three factors. First, Moore (2000: Table 1 footnotes) elected to use only two criteria to rank sea ice: number of ice-free days between Point Barrow and Prudhoe Bay and number of days with $50 \%$ ice cover conditions between Point Barrow and Prudhoe Bay. Second, Moore (2000) re-scored the original Navy/NOAA ranks to include only the years of her study (1982-91). Finally, ranks are relative and may change with inclusion of more years. Moore (2000) had fewer years that ultimately determined the overall ranks, regardless of criteria used. Though useful in describing ranks of annual sea-ice conditions in the western and central Beaufort Sea at a large spatial scale, the rankings provided by Navy/NOAA may not be at an appropriate resolution to deal with small-scale ecological questions (Weins, 1989; Levin, 1992). Future researchers may wish to incorporate other metrics of ice cover and ice conditions obtained simultaneously with whale sightings in their analysis of bowhead whale distribution and behavior.

Our methods are unbiased relative to survey effort or sighting conditions (Cosens et al., 1997; Cosens and Innes, 2000) and results are representative of actual distributions of fall bowhead whales using nearshore $\left(70^{\circ}\right.$ to $\left.72^{\circ} \mathrm{N}\right)$ waters in the central Alaskan Beaufort Sea (but see Moore, 2000; Moore et al., 2000). Since we were not interested in deriving density or population estimates, any biases related to survey methodology are reduced (Eberhardt, 1978; Burnham et al., 1980). Our surveys encompassed the peak of fall movements (Sept-Oct; Moore and Reeves, 1993) with nearly complete coverage of the entire study area 
each year. We recognize the potential for sex- and agespecific segregation to occur either spatially or temporally during fall migration of bowhead whales in the Beaufort Sea (Braham, 1995; George et al., 1995; Cosens and Innes, 2000; but see Moore and Reeves, 1993:351). However, the monitoring protocol precluded an analysis of differences in migration axes relative to sex-age cohorts. Similarly, since the survey protocol does not require circling to document all whale sightings, the number of calves observed is probably biased low (Moore and Reeves, 1993:351; Cosens and Blouw, 2003). Sightings of cowcalf pairs represent a small fraction of total bowhead whale sightings in any given year; however, number of calves sighted may be higher in years when large feeding aggregations are sighted simply because more time is spent circling larger groups (Minerals Management Service, unpubl. data; see also Ljungblad et al., 1986a, c).

Patterns of association of bowhead whales and ice are becoming increasingly clear. The most logical explanation for the observed pattern in bowhead whale distribution was that in years of heavy ice conditions, developing landfast ice limited availability of shallow nearshore habitat, thus necessitating use of leads and ice openings in deeper water for migratory movements. Our results in conjunction with previous work (Ljungblad et al., 1986c; Moore and Clarke, 1992; Moore and Reeves, 1993; Moore, 2000; Moore et al., 2000) clearly demonstrate a pattern of association between bowhead whales observed during the fall migration and sea-ice conditions. While factors other than sea ice may have localized effects on individual animals, the overall distance from shore of the surveyed population within the central Alaskan Beaufort Sea is most strongly affected by annual sea-ice conditions. In this study, we did not consider behavior per se (e.g., feeding, milling, and swimming) as a factor in describing bowhead whale distribution relative to sea-ice conditions. Future analyses of bowhead whale distribution should consider inclusion of behavior because whale distribution and movements are likely a function of the whale's proximate response to environmental cues. Furthermore, we recommend that future researchers on bowhead whale distribution expand their data collection techniques to incorporate potentially important covariates at the same spatiotemporal scale that could be included in a more robust multivariate framework (see McGarigal et al., 2000).

\section{ACKNOWLEDGEMENTS}

Funding for aerial surveys was provided by the U.S. Minerals Management Service, Alaska Outer Continental Shelf Region. We thank the numerous observers, data recorders, and team leaders from SAIC Maritime Service, Naval Ocean Systems Center, and Minerals Management Service associated with this project. We appreciate the continued support of the Minerals Management Service. We greatly appreciate the services, knowledge, and skills provided by pilots who participated in the surveys, as well as support from the Office of Aircraft Services, Anchorage. Information sharing between this project, North Slope Borough Department of Wildlife Management, Alaska Eskimo Whaling Commission, and the Whalers Communication Center has proven beneficial. Project data collection and field analysis programs used throughout were designed by John Bennett (SAIC), John Dunlap (MMS), and Tom Murrell (MMS). Ian Moore, Matt Heller, and Michael Hay assisted with data management and figure preparation. Thanks to Charles Monnett, Minerals Management Service, for very helpful discussions and editorial suggestions. National Marine Fisheries Science in Anchorage, Alaska, has been liaison to the project since its inception, and we particularly thank Brad Smith. We also acknowledge the National Ice Center for providing severity rankings and concentrations for sea ice. This paper benefited greatly from comments provided by Susan Cosens, Karen McCullough, and two anonymous reviewers. The findings and conclusions in this paper are those of the authors and do not necessarily represent the views of the funding agency. Any mention of trade names is purely coincidental and does not represent endorsement by the government.

\section{REFERENCES}

ANGLISS, R.P., and LODGE, K.L. 2002. Bowhead whale (Balaena mysticetus): Western Arctic stock. In: Angliss, R.P., and Lodge, K.L., eds. Alaska marine mammal stock assessments, 2002. Seattle, Washington: U.S. Department of Commerce, NOAA Technical Memorandum NMFS-AFSC-133. 171-176.

BARNES, P., BELON, A., COON, A., HANSON, A., HARRISON, W., HOSKINS, E., HUNT, W., KOVACS, A., MARTIN, S., NASKE, C.M., NELSON, R., PRITCHARD, R., REIMNITZ, E., SACKINGER, W., STRINGER, W., and WEEKS, W. 1978. The sea ice environment. In: Shapiro, L., and Barry, R.G., eds. Environmental assessment of the Alaskan continental shelf interim synthesis: Beaufort/Chukchi Sea. Boulder, Colorado: U.S. Department of Commerce, NOAA Environmental Research Laboratories. 3-55.

BRAHAM, H.W. 1995. Sex and size composition of bowhead whales landed by Alaskan Eskimo whalers. In: McCartney, A.P., ed. Hunting the largest animals: Native whaling in the western Arctic and Subarctic. Studies on Whales 3, Occasional Publication 36. Edmonton: Canadian Circumpolar Institute. 281-313.

BURNHAM, K.P., ANDERSON, D.R., and LAAKE, J.L. 1980. Estimation of density from line transect sampling of biological populations. Wildlife Monographs 72. 202 p.

BURNS, J.J., SHAPIRO, L.W., and FAY, F.H. 1981. Ice as marine mammal habitat in the Bering Sea. In: Hood, D.W., and Calder, J.A., eds. The eastern Bering Sea shelf: Oceanography and resources. Seattle, Washington: University of Washington Press. $781-797$.

CHAPMAN, C.F. 1977. Piloting, seamanship and small boat handling. New York: Hearst Books.

COSENS, S.E., and BLOUW, A. 2003. Size- and age-class segregation of bowhead whales summering in northern Foxe Basin: A photogrammetric analysis. Marine Mammal Science 19:284-296. 
COSENS, S.E., and INNES, S. 2000. Distribution and numbers of bowhead whales (Balaena mysticetus) in northwestern Hudson Bay in August 1995. Arctic 53(1):36-41.

COSENS, S.E., QAMUKAQ, T., PARKER, B., DUECK, L.P., and ANARDJUAK, B. 1997. The distribution and numbers of bowhead whales, Balaena mysticetus, in northern Foxe Basin in 1994. Canadian Field-Naturalist 111:381-388.

EBERHARDT, L.L. 1978. Transect methods for population studies. Journal of Wildlife Management 42:1-31.

ESRI(ENVIRONMENTAL SYSTEMS RESEARCH INSTITUTE, INC.) 1999. Arcview GIS v 3.2. Redlands, California: ESRI.

GEORGE, J.C., SUYDAM, R.S., PHILO, L.M., ALBERT, T.F., ZEH, J.E., and CARROLL, G.M. 1995. Report of the spring 1993 census of bowhead whales, Balaena mysticetus, off Point Barrow, Alaska, with observations on the 1993 subsistence hunt of bowhead whales by Alaska Eskimos. Report of the International Whaling Commission 45:371-384.

GEORGE, J.C., ZEH, J.E., SUYDAM, R.S., and CLARK, C.W. 2004. Abundance and population trends (1978-2001) of Western Arctic bowhead whales surveyed near Barrow, Alaska. Marine Mammal Science 20:755-773.

LANDINO, S.W., TREACY, S.D., ZERWICK, S.A., andDUNLAP, J.B. 1994. A large aggregation of bowhead whales (Balaena mysticetus) feeding near Point Barrow, Alaska, in late October 1992. Arctic 47(3):232-235.

LEVIN, S.A. 1992. The problem of pattern and scale in ecology. Ecology 73:1943-1967.

LJUNGBLAD, D.K., MOORE, S.E., and CLARKE, J.T. 1986a. Assessment of bowhead whale (Balaena mysticetus) feeding patterns in the Alaskan Beaufort and northern Chukchi seas via aerial surveys, fall 1979-1984. Report of the International Whaling Commission 36:265-272.

LJUNGBLAD, D.K., MOORE, S.E., CLARKE, J.T., and BENNETT, J.C. 1986b. Aerial surveys of endangered whales in the northern Bering Sea, eastern Chukchi and Alaskan Beaufort seas, 1985: With a seven year review, 1979-1985. Report for the U.S. Minerals Management Service by Naval Ocean Systems Center. NOSC TR 1111. San Diego, California: NOSC. 443 p. LJUNGBLAD, D.K., MOORE, S.E., and VAN SCHOIK, D.R. 1986c. Seasonal patterns of distribution, abundance, migration and behavior of the western Arctic stock of bowhead whales, Balaena mysticetus, in Alaskan seas. Report of the International Whaling Commission (Special Issue 8):177-205.

LOWRY, L.F. 1993. Foods and feeding ecology. In: Burns, J.J., Montague, J.J., and Cowles, C.J., eds. The bowhead whale. The Society for Marine Mammalogy, Special Publication No. 2. Lawrence, Kansas: Allen Press Inc. 201-238.
LOWRY, L.F., and FROST, K.J. 1984. Foods and feeding of bowhead whales in western and northern Alaska. Scientific Reports of the Whales Research Institute 35:1-16.

MATE, B.R., KRUTZIKOWSKY, G.K., and WINSOR, M.H. 2000. Satellite-monitored movements of radio-tagged bowhead whales in the Beaufort and Chukchi seas during the late-summer feeding season and fall migration. Canadian Journal of Zoology 78(7):1168-1181.

McGARIGAL, K., CUSHMAN, S., and STAFFORD, S. 2000. Multivariate statistics for wildlife and ecology research. New York: Springer-Verlag. 283 p.

MOORE, S.E. 2000. Variability of cetacean distribution and habitat selection in the Alaskan Arctic, autumn 1982-91. Arctic 53(4):448-460.

MOORE, S.E., and CLARKE, J.T. 1992. Patterns of bowhead whale (Balaena mysticetus) distribution and abundance near Barrow, Alaska, in fall 1982-1989. Marine Mammal Science 8:27-36.

MOORE, S.E., and DeMASTER, D.P. 1997. Cetacean habitats in the Alaskan Arctic. Journal of Northwest Atlantic Fishery Science 22:55-69.

MOORE, S.E., and REEVES, R.R. 1993. Distribution and movement. In: Burns, J.J., Montague, J.J., and Cowles, C.J., eds. The bowhead whale. The Society for Marine Mammalogy, Special Publication No. 2. Lawrence, Kansas: Allen Press Inc. 313-386.

MOORE, S.E., DeMASTER, D.P., and DAYTON, P.K. 2000. Cetacean habitat selection in the Alaskan Arctic during summer and autumn. Arctic 53(4):432-447.

NAVY/NOAA. 2002. United States Navy-National Oceanographic and Atmospheric Administration Joint Ice Center: Seasonal Outlook Western Arctic Ice, 2002. Prepared by Naval Polar Oceanography Center for Naval Oceanography Command. Available on-line at http://www.natice.noaa.gov/pub/outlooks/ West_Arctic/2003/westlook03.doc.

SHELDEN, K.E.W., and RUGH, D.J. 1995. The bowhead whale, Balaena mysticetus: Its historic and current status. Marine Fisheries Review 57:1-20.

STATSOFT, Inc. 1995. STATISTICA ${ }^{\mathrm{TM}}$ for windows. Tulsa, Oklahoma: StatSoft, Inc.

TREACY, S.D. 2002. Aerial surveys of endangered whales in the Beaufort Sea, fall 2001. OCS Study, MMS 2002-14. 111 p. Available from Minerals Management Service, 3801 Centerpoint Dr., Suite 500, Anchorage, Alaska 99503-5820, U.S.A.

WEINS, J.A. 1989. Spatial scaling in ecology. Functional Ecology 3:385-397.

WILKINSON, L., and COWARD, M. 1999. Linear models II: Analysis of variance. In: SYSTAT 9 Statistics I. Chicago, Illinois. 431-486. 